BHI-00823

Rev. 0

\title{
Site Specific Health \& Safety Plan, 233-S Decontamination and Decommissioning
}

Author

J. E. Fasso

Date Published

February 1997

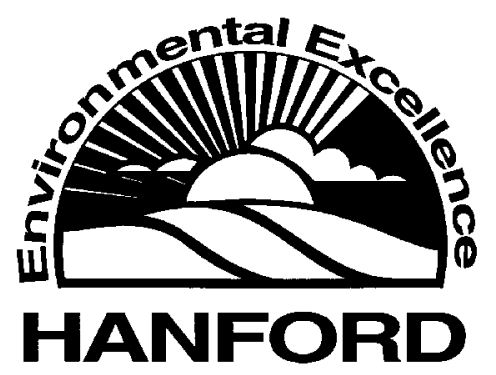

Prepared for the U.S. Department of Energy

Office of Environmental Restoration and

Waste Management

Bechtel Hanford, Inc.

Richland, Washington 
TRADEMARK DISCLAIMER

Reference herein to any specific commercial product, process, or

service by trade name, trademark, manufacturer, or otherwise, does

not necessarily constitute or imply its endorsement,

recommendation, or favoring by the United States Government or any agency thereof or its contractors or subcontractors.

This report has been reproduced from the best available copy. Available in paper copy and microfiche.

Available to the U.S. Department of Energy

and its contractors from

Office of Scientific and Technical Information

P.O. Box 62

Oak Ridge, TN 37831

(615) $576-8401$

Available to the public from the U.S. Department of Commerce

National Technical Information Service

5285 Port Royal Road

Springfield, VA 22161

(703) $487-4650$

Printed in the United States of America

DISCLM-5.CHP (8-91) 
$\underline{\text { Section }}$

1. PROJECT DESCRIPTION $\ldots \ldots \ldots \ldots \ldots \ldots \ldots \ldots \ldots \ldots \ldots \ldots \ldots \ldots \ldots \ldots \ldots$

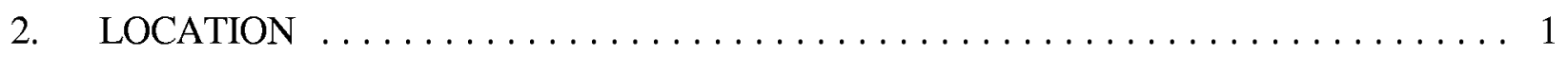

3. FACILITY SITE DESCRIPTION $\ldots \ldots \ldots \ldots \ldots \ldots \ldots \ldots \ldots \ldots \ldots \ldots \ldots \ldots \ldots \ldots \ldots$

4. PROPOSED PERSONNEL AND JOB FUNCTIONS $\ldots \ldots \ldots \ldots \ldots \ldots \ldots \ldots \ldots$

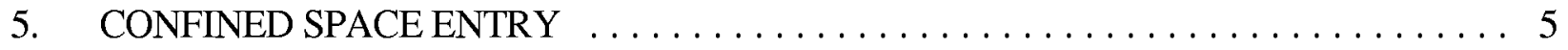

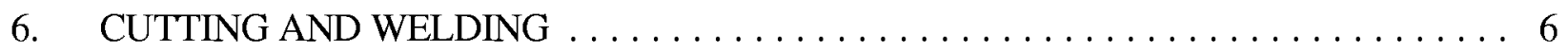

7. OTHER POTENTIAL HAZARDS $\ldots \ldots \ldots \ldots \ldots \ldots \ldots \ldots \ldots \ldots \ldots \ldots \ldots \ldots \ldots \ldots$

8. HAZARD MITIGATION AND CONTROL $\ldots \ldots \ldots \ldots \ldots \ldots \ldots \ldots$

9. CHEMICAL OR RADIOLOGICAL HAZARD EVALUATION $\ldots \ldots \ldots \ldots \ldots \ldots$

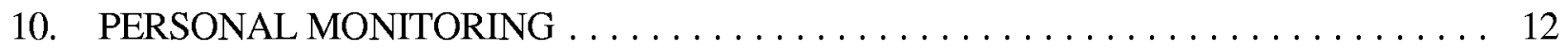

11. AMBIENT AIR AND SITE MONITORING PROCEDURES . . . . . . . . . . . . . 12

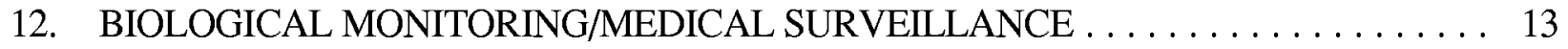

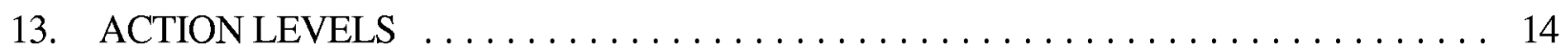

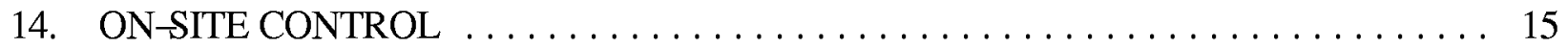

15. PERSONAL PROTECTIVE EQUIPMENT $\ldots \ldots \ldots \ldots \ldots \ldots \ldots \ldots \ldots \ldots \ldots \ldots$

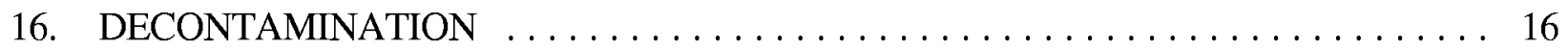

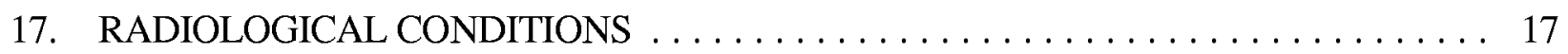

18. RADIOLOGICAL CONTROL TECHNICIAN COVERAGE $\ldots \ldots \ldots \ldots \ldots \ldots \ldots$ 
$\underline{\text { Section }}$

19. PERSONAL PROTECTIVE EQUIPMENT FOR

RADIOLOGICAL HAZARDS $\ldots \ldots \ldots \ldots \ldots \ldots \ldots \ldots \ldots \ldots \ldots \ldots \ldots$

20. RADIATION DOSIMETRY EXTERNAL $\ldots \ldots \ldots \ldots \ldots \ldots \ldots \ldots \ldots \ldots \ldots$

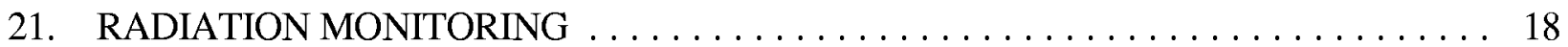

22. ON-SITE ORGANIZATION AND COORDINATION . . . . . . . . . . . . . . . 19

23. TRAINING/SPECIAL REQUIREMENTS $\ldots \ldots \ldots \ldots \ldots \ldots \ldots \ldots \ldots \ldots \ldots$

24. SANITATION REQUIREMENTS $\ldots \ldots \ldots \ldots \ldots \ldots \ldots \ldots \ldots \ldots \ldots \ldots \ldots$

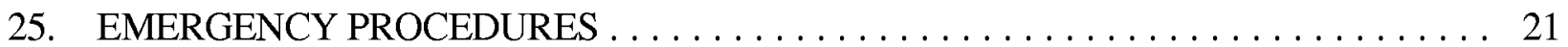

Appendix A. Field Change Authorization $\ldots \ldots \ldots \ldots \ldots \ldots \ldots \ldots \ldots \ldots, 31$

Figure 1. Map of Work Locations . ......................... 32

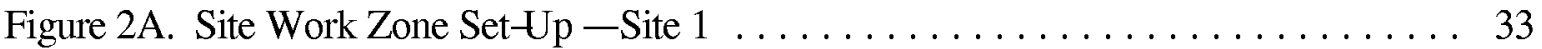

Figure 2B. Site Work Zone Set-Up —Sites 2-4 ...................... 34

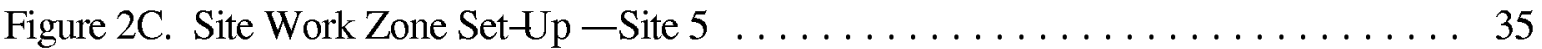




\section{PROJECT DESCRIPTION}

The Hanford Site is a 560-square mile Federal facility located in southeastern Washington State along the Columbia River used from 1943 until 1990 to produce nuclear materials for the nation's defense. In July 1989, the Hanford Site was listed on the National Priorities List (NPL) under the Comprehensive Environmental Response, Compensation, and Liability Act (CERCLA) of 1980 as amended by the Superfund Amendments and Reauthorization Act (SARA) of 1986. The Hanford Site was divided and listed as four NPL sites: the 100 Area, the 200 Area, the 300 Area, and the 1100 Area. The deactivated 233-S Plutonium Concentration Facility (233-S Facility) located in the 200 Area is the subject of this Health and Safety Plan.

The 233-S Facility operated from January 1952 until July 1967 at which time the building entered the U.S. Department of Energy's (DOE) Surplus Facility Management Program as a retired facility. The facility has since undergone severe degradation due to exposure to extreme weather conditions. A freeze and thaw cycle occurred at the Hanford Site during February 1996, which caused cracking failure of portions of the building roof. This resulted in significant infiltration of water into the facility, which creates a pathway for potential release of radioactive material into the environment (air and/or ground). Additionally, the weather caused existing cracks in concrete structures of the building to lengthen, thereby increasing the potential for failed confinement of the radioactive material in the building. Differential settlement has also occurred causing portions of the facility to separate from the main building structure, increasing the potential for release of radioactive material to the environment. An expedited response is proposed to remove this threat and ensure protection of human health and the environment. On this premise it is intended that the $233-S$ Facility removal action be performed as a CERCLA Time-Critical Project being conducted under the Pilot Hanford Environmental Restoration (ER) Initiative.

\section{LOCATION}

The 233-S facility is located in the 200 West Area of the Hanford Site. The facility is adjacent to and north of the Reduction-Oxidation Plant (REDOX). 


\section{FACILITY SITE DESCRIPTION}

The 233-S Plutonium Concentration Facility is composed of the 233-S Process Building and the 233-SA Exhaust Filter Building. The 233-S Plutonium Concentration Facility is a reinforced concrete structure $11.3 \mathrm{~m}(37 \mathrm{ft})$ by $25.7 \mathrm{~m}(86 \mathrm{ft})$ with $20.3 \mathrm{~cm}(8 \mathrm{in}$.$) thick walls and 15.2 \mathrm{~cm}(6 \mathrm{in}$.$) thick$ floors. The building consists of a process cell, a non-process pipe gallery, control room, special work permit (SWP) change room, lavatory, equipment room, a loadout and decontamination room, two can storage rooms, and five air locks.

The 233-SA Filter Building is a one-story, $4.9 \mathrm{~m}(16 \mathrm{ft})$ by $7.3 \mathrm{~m}$ ( $24 \mathrm{ft})$ reinforced concrete structure with $15.2 \mathrm{~cm}(6 \mathrm{in}$.) walls. The filter building is located on a $7.3 \mathrm{~m}(24 \mathrm{ft})$ square, $20.3 \mathrm{~cm}(8 \mathrm{in}$.) thick reinforced concrete pad at the northeast corner of the 233-S Plutonium Concentration Facility. The filter building contains two parallel filter banks. Each bank has a prefilter and a series of double highefficiency particulate air (HEPA) filters with its own exhaust fan, $7.6 \mathrm{~m}$ ( $25 \mathrm{ft}$ ) high metal stack, and sampling equipment. The fans and stacks are located to the north of the building and are designated 296-S-7 East and 296-S-7 West.

The major areas of concern in preparing the 233-S Facility for removal are the process cell, the process pipe trench and the load out and decontamination room. These areas contain the major portion of the fissile material inventory and are the more severely contaminated areas.

The process cell is a four-story high bay with $30.5 \mathrm{~cm}$ (12 in.) thick concrete walls and is divided into two zones. The two zones, the process hood and the viewing room, are separated with a partition of transparent panels and reinforced structural steel. The viewing room has open-grate flooring on each of the upper three levels with the original access ladder in the southwest corner.

The process hood is $9.7 \mathrm{~m}(32 \mathrm{ft})$ high and contains a process system array with criticality safe process vessels up to $7 \mathrm{~m}(23 \mathrm{ft}$ ) tall and $17.8 \mathrm{~cm}$ ( $7 \mathrm{in}$.) inside diameter. The viewing room provides access to upper levels of the process hood via three open grating walkways along the east and south sides of the process hood enclosure. The walkways are located so as to divide the height of the cell into approximately equal segments of $2.4 \mathrm{~m}(8 \mathrm{ft})$. The east and south faces of the hood are constructed of Lucite panels that are supported by stainless steel frame support members. There are usually two Lucite panels in height between each level and in some cases double panels have been installed. At the north end of the hood, the wall at the upper level of the hood supports electric and process instrumentation equipment. 
The pipe trench is a concrete subgrade structure running between the REDOX Building and the southeast corner of the 233-S Building. The pipe trench is divided into two parallel sections to separate radiological solution transfer lines and nonradiological piping. The concrete cover blocks have metal plates concealing recessed lifting bails. A neptunium pipe trench with metal covers was added in the 1962 upgrade and is located adjacent to the pipe trench.

The load out and decontamination room is located on the north side of the process hood. The loadout hood is located on the south side, or common wall with the process hood, and is a containment type work station.

The remaining areas of the 233-S Facility are only slightly contaminated and will require less effort to decontaminate. The non-process pipe gallery and the equipment room contain considerable equipment and facility systems and will therefore require an extensive effort in their removal.

The pipe gallery contains non-process support lines from the REDOX Building that enter the area through the viewing room. Equipment in the room includes instrument lines, steam lines, a chemical makeup tank and a variety of control panels. The control panels are separated from the process area by plastic panels which create an isolated control room. The non-process lines should not be internally contaminated by radionuclides.

The equipment room contains the necessary equipment, ducting and wiring required to provide and control make-tp air to the building. Much of the ducting is insulated with asbestos materials. Airborne contamination may have deposited on equipment surfaces during upset operation conditions.

The facility water and non-process steam lines have been disconnected, the floor drains have been filled with grout, and the electrical utilities have been deactivated. Temporary construction power has been installed to maintain alarms, ventilation fans, lighting, and heating. One nonvalve $1.9 \mathrm{~cm} \mathrm{(3/4} \mathrm{in.)}$ water line on the fire hydrant line is still active inside the SWP change room of 233-S Building.

The removal action for the $233-\mathrm{S}$ Facility will involve those activities needed and/or required to prepare the facility for demolition and disposal. 
The 233-S Facility has been inactive for over 25 years and has no identified future use that would justify a partial cleanup/maintenance approach. The building is a radioactively-eontaminated facility that has undergone severe structural deterioration due to exposure to extreme weather conditions. The major inventory of fissile material is located in the vessels of the process hood, and contamination is found throughout most of the facility. Nonradioactive hazardous materials in the facility include residual chemicals in the process lines, friable asbestos and lead paint throughout the facility and the normal hazardous materials associated with lights, switches, pumps and motors.

Removal of the $233-S$ Facility will be performed in a sequential progression of operations designed to initially eliminate the most hazardous conditions followed by a logical course of operations for removal. The major goals associated with this method of operation are:

C Fissile material removal-completion of the operations associated with this goal is paramount in eliminating the threat of an accidental criticality and removing the major source of radioactive contamination.

C Facility equipment and systems removal -completion of these operations will prepare the facility for demolition/dismantlement and will eliminate additional sources of contamination.

C Facility surface decontamination -the total removal of surface contaminants will permit facility removal to be performed by conventional demolition practices whereas the fixing of penetrated surface contaminants will lead to a more complex system of building dismantlement.

C Facility characterization -the conduct of radiation surveys and the analyses of select facility material samples will provide decisional information that will dictate the method of facility removal that can be used and the category of construction wastes that will be disposed.

C Facility removal -removal of the building structures by conventional demolition or by selective dismantlement will determine the waste forms to be processed and will conclude the ultimate goal of this project.

C Waste product disposal -the characterization, packaging, storage and transport of waste to disposal will be conducted throughout the duration of this project. Each waste type will be processed and managed in accordance with appropriate regulations. 
C Facility area stabilization -the footprint and associated areas of the 233-S Facility will be processed to either a radiological releasable condition or be protected by surface capping until ensuing remedial actions can be performed.

While many significant accomplishments will be associated with each of these goals, the completion of each goal will be considered a schedule milestone that will trigger a redirection of work effort. In some cases the completion of a goal may serve as a hold point in the project if higher priorities are identified or funding must be diverted.

\section{PROPOSED PERSONNEL AND JOB FUNCTIONS}

Project Coordinator: $\underline{\text { S. A. Thoren }}$

Field Superintendent: $\underline{\text { C. W. Blankingship }}$

Craft Supervisor: $\underline{\text { J. L. Davis }}$

\section{PROPOSED WORK TEAM}

Radiological Control Technician (RCT) -4

Site Safety Officer (SSO) -1 to 2

Sampling Team Leader -1

\begin{tabular}{l}
\hline Samplers -2 to 6 \\
\hline Riggers -2 \\
\hline D\&D -6 \\
\hline Operators -1 \\
\hline Supervisor -1 \\
\hline
\end{tabular}

\section{$\underline{\text { JOB FUNCTION }}$}

Carry out all RCT functions.

Carry out all SSO functions.

Supervise sampling activities.

Perform sampling activities.

Erect scaffolding, rigging.

D\&D.

Crane operator.

Supervise and direct work activities

\section{CONFINED SPACE ENTRY}

All entry to confined spaces will require a Confined Space Entry Permit, Activity Hazard Analysis and follow the requirements of BHI-SH-02, Vol. 3, Proc. 4.1.1. 


\section{CUTTING AND WELDING}

Welding and cutting activities may be required to support the project. Personnel operating welding or cutting equipment shall wear welding/cutting goggles, and/or welding hood and the appropriate flame retardant clothing for the task at hand. The two types of flame retardant clothing available are leathers and brown coveralls (red coveralls in radiation areas). Brown (red) coveralls are flame retardant and can be worn in place of leathers. Respiratory protection may be required during cutting, grinding, and other activities producing respirable dusts, fumes, or vapors. PPE determination shall be made by the SSO or RCT Supervisor with concurrence from the Superintendent.

A combustible gas analyzer and PID will be used to monitor for potential combustible and organic vapors. A Hot Work Permit is required and follow guidance from BHI-SH-02, VOL. 4, Proc. 6.4.3. Flash arrestors shall be in place on the oxy/acetylene regulators. Ground fault circuit interrupters (GFCIs) shall be utilized when using a generator as a source of power (i.e., to run heaters, grinders, lights, etc.). Gas cylinders need to be chained and stored in a secure, upright position.

\section{OTHER POTENTIAL HAZARDS}

$\begin{array}{ll}\mathrm{X} & \text { Chemical } \\ \mathrm{y} & \text { Radiological } \\ \mathrm{X} & \text { Fire/Explosion } \\ \mathrm{y} & \text { Temperature-Heat \& Cold Stress } \\ \mathrm{y} & \text { Electrical } \\ \mathrm{y} & \text { Machinery/Mechanical Equipment } \\ \mathrm{y} & \text { Noise }\end{array}$

\begin{tabular}{ll}
$\mathrm{X}$ & Trips, Slips, Falls \\
\cline { 1 - 1 } $\mathrm{X}$ & Asbestos/Lead \\
$\mathrm{X}$ & Fall Protection/Rigging \\
$\mathrm{X}$ & Overhead Hazards \\
$\mathrm{y}$ & Unstable/Uneven Terrain \\
$\mathrm{y}$ & Other -Describe Below, Step 9.
\end{tabular}

Task-specific hazards will be addressed in the applicable Activity Hazard Analysis (AIA).

\section{HAZARD MITIGATION AND CONTROL}

Chemical -See Items 9 through 16.

Radiological -See Items 17 through 21 . Engineering controls (ventilation, capture velocity, containment, and humidity control) will be used as applicable to keep exposures as low as reasonably achievable. 
Fire/Explosion -Site activities and procedures will be geared toward the prevention of fires and explosions through adherence to the following precautions and procedures provided in BHI-SH-02, Vol. 4.

C Smoking will not be allowed within the controlled areas (contamination reduction and exclusion zones).

C Monitoring for combustible gases will be required immediately prior to any cutting operations if a combustion potential exists. See Item 13 for combustible gas action levels.

$\mathrm{C} \quad$ Fire watch during cutting and grinding.

Heat Stress -Heat stress may be a concern, depending on the weather conditions. When temperatures at the site are above $80 \mathrm{EF}$ and especially if PPE above Level D is in use, site personnel shall be alert to the symptoms of heat stress, for example:

\begin{tabular}{||l|l|l||}
\hline \multicolumn{1}{|||}{ HEAT STRESS } & \multicolumn{1}{|c|}{ SYMPTOMS } & \multicolumn{1}{c|}{ FIRST AID } \\
\hline Heat Exhaustion & $\begin{array}{l}\text { Pale, extreme sweating, } \\
\text { headache, dizzy, shortness of } \\
\text { breath, and nausea }\end{array}$ & $\begin{array}{l}\text { Seek medical aid, give sips of } \\
\text { water (if conscious), remove } \\
\text { clothing, move to cool area, } \\
\text { apply moist towels, lay down, } \\
\text { and elevate legs }\end{array}$ \\
\hline Heat Stroke & $\begin{array}{l}\text { Dry skin, drowsy or } \\
\text { unconscious, red face, fatigue, } \\
\text { incoherent, and hallucinations }\end{array}$ & $\begin{array}{l}\text { Seek medical aid, give sips of } \\
\text { water (if conscious), remove } \\
\text { clothing, move to cool area, } \\
\text { apply moist towels, lay down, } \\
\text { and elevate legs }\end{array}$ \\
\hline
\end{tabular}

When the temperature reaches $90 \mathrm{EF}$, personnel will be monitored for heat stress by measuring the wet bulb/globe temperature (WBGT). Work/rest periods will be adjusted according to the guidance stated in BHI-SH-02, Vol. 3, 4.1.2, "Temperature Extremes." Sufficient cool (but not iced) water and disposable drinking cups will be provided in a shaded rest area in the support zone. Engineering controls, such as solar shielding, etc., will be applied when and where appropriate. Because this work will take place in Level D, C and B PPE, heat stress indicators will be discussed with the workers in the pre-job safety briefing and tail-gate meetings as necessary. Workers will use safe work practices including drinking cool water, taking rest breaks as necessary, and using the "buddy system" to keep an eye on each other and watch for any heat stress symptoms. A trailer will also be provided for cool down rest periods. 
Electrical -Ground fault circuit interrupters shall be used with all extension cords. Electrical equipment operating at 50 volts or more with a current capacity of 1 milliamp or more shall be deenergized from all sources, isolated, and locked out in accordance with BHI-SH-02, 1.1.1, 'Hazardous Energy Control." Follow guidance stated in BHI-SH-02, 3.2.1, "Electrical Safety Practices."

Machinery/Mechanical Equipment/Overhead Hazards -All equipment to be brought on sight will be inspected by the Supervisor and SSO. Any defects, safety hazards, or problems will be repaired or otherwise corrected prior to entry.

Trips/Slips/Falls and Unstable/Uneven Terrain - The chance of personal injury due to falls from tripping or slipping is increased when wearing PPE. Personnel must be aware of this and take care to think ahead and plan movements to allow for reduced visibility and mobility. Personnel will wear substantial footwear.

Safe access such as ramps, ladders, walkways, or similar devices will be provided for the work area at all times and regularly inspected by the SSO.

Noise -Hearing protection will be required when working in environments where the noise exceeds $85 \mathrm{~dB}$ (e.g., around heavy equipment, etc.) Areas where hearing protection is required will be posted.

Fall Protection/Rigging - These situations will be addressed in a task specific Activity Hazard Analysis for thorough project planning. The requirements of BHI-SH-02, VOL.3, 3.2.4, "Fall Protection" and the Hanford Hoisting and Rigging Manual will be followed.

Asbestos/Lead -Lead based paint and asbestos are prevalent throughout the building. Abatement shall be done with trained workers; as well as, personnel shall be blood lead baselined when working with lead materials. 


\section{CHEMICAL OR RADIOLOGICAL HAZARD EVALUATION}

\section{Waste Media}

$\underline{X}$ Airborne Contamination

$\mathrm{X}$ Surface Contamination

$\mathrm{X}$ Contaminated Soil

- Contaminated Groundwater Contaminated Surface Water

$\mathrm{X}$ Solid Waste

$\mathrm{X}$ Liquid Waste Sludge
Hazardous Characteristics

\begin{tabular}{ll}
$\mathrm{X}$ & Ignitable (IGN) \\
\cline { 1 - 1 } $\mathrm{X}$ & Corrosive (COR) \\
$\mathrm{y}$ & Reactive (RX) \\
$\mathrm{y}$ & Explosive (EX) \\
$\mathrm{X}$ & Toxic (TX), (non-radiological) \\
$\mathrm{y}$ & Carcinogen (CX) \\
$\mathrm{X}$ & Radioactive (RAD)
\end{tabular}

Note: This task may or may not involve the possibility of exposure to the substances listed below at concentrations in quantities which may be hazardous to the health of site personnel. The list below may be refined after sampling. Radiological concerns are addressed in Items 17 through 21.

Abbreviations: Inhalation-INH, Ingestion-ING, Irritant-IRR, Ignitable-IGN, Corrosive-COR, Reactive-RX, Explosive-EX, Toxic-TX, Carcinogenic-CX, Poison-P, Solid-s, Liquid-L, y-possible exposure route.

Primary Hazard Rating: negligible-neg, Low-to, moderate-mod, high-hi, and/or extreme-ext.

\begin{tabular}{|c|c|c|c|c|c|c|c|c|c|}
\hline 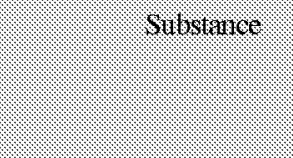 & INII & INa & 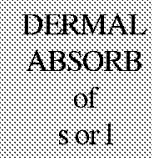 & s & 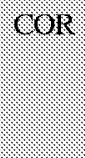 & IIRR & 194 & $18 \times 1.1 \times$ & 0111112 \\
\hline Acetylene Tetrabromide & $\mathrm{y}$ & $\mathrm{y}$ & $\mathrm{y}$ & $\mathrm{y}$ & N/A & $\mathrm{y}$ & N/A & $\mathrm{y}$ & \\
\hline Asbestos & $\mathrm{y}$ & $\mathrm{y}$ & N/A & N/A & N/A & $\mathrm{N} / \mathrm{A}$ & $\mathrm{N} / \mathrm{A}$ & NA & $\mathrm{CX}$ \\
\hline Hexone & $\mathrm{y}$ & $\mathrm{y}$ & N/A & $\mathrm{y}$ & N/A & $\mathrm{y}$ & $\mathrm{y}$ & $\mathrm{y}$ & \\
\hline Lead & $\mathrm{y}$ & $\mathrm{y}$ & N/A & $\mathrm{N} / \mathrm{A}$ & $\mathrm{N} / \mathrm{A}$ & $\mathrm{N} / \mathrm{A}$ & $\mathrm{N} / \mathrm{A}$ & N/A & \\
\hline Mercury, metallic & $\mathrm{y}$ & N/A & $\mathrm{y}$ & $\mathrm{y}$ & N/A & N/A & N/A & N/A & \\
\hline Methylene chloride & $\mathrm{y}$ & $\mathrm{y}$ & $\mathrm{y}$ & $\mathrm{y}$ & $\mathrm{N} / \mathrm{A}$ & $\mathrm{y}$ & $\mathrm{y}$ & $\mathrm{y}$ & $\mathrm{CX}$ \\
\hline Neptunium & $\mathrm{y}$ & $\mathrm{y}$ & N/A & $\mathrm{N} / \mathrm{A}$ & N/A & N/A & N/A & N/A & $\mathrm{TX}, \mathrm{CX}$ \\
\hline Nitric acid & $\mathrm{y}$ & $\mathrm{y}$ & $\mathrm{y}$ & $\mathrm{y}$ & $\mathrm{y}$ & $\mathrm{y}$ & N/A & $\mathrm{y}$ & \\
\hline
\end{tabular}




\begin{tabular}{|c|c|c|c|c|c|c|c|c|c|}
\hline 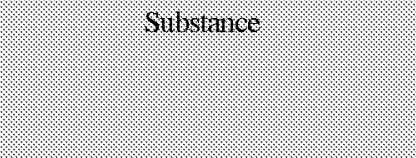 & INII & $\frac{1 \times 10}{.}$ & 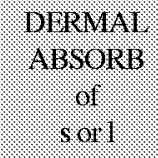 & s. & SOR & IRRR & $19 \pi$ & rexis & OIIIIER \\
\hline Polyschlorinated biphenyls (PCBs) & $\mathrm{y}$ & $\mathrm{y}$ & $\mathrm{y}$ & N/A & N/A & $\mathrm{y}$ & N/A & N/A & $\mathrm{CX}$ \\
\hline Plutonium & $\mathrm{y}$ & $\mathrm{y}$ & N/A & N/A & N/A & N/A & N/A & N/A & $\mathrm{TX}, \mathrm{CX}$ \\
\hline \multicolumn{10}{|l|}{ Ruthenium } \\
\hline Silica, crystalline & $\mathrm{y}$ & $\mathrm{y}$ & N/A & N/A & N/A & N/A & N/A & N/A & $\mathrm{CX}$ \\
\hline Uranium & $\mathrm{y}$ & $\mathrm{y}$ & $\mathrm{N} / \mathrm{A}$ & $\mathrm{Y}$ & N/A & $\mathrm{y}$ & $\mathrm{y}$ & $\mathrm{y}$ & $\mathrm{TX}, \mathrm{CX}$ \\
\hline
\end{tabular}

Substance: This task will involve describing the PELs for the substances expected to be present on site. List the permissible exposure level (PEL), give an IDLH value (if available), and describe any known health effects.

\begin{tabular}{|c|c|c|c|}
\hline Silostance & 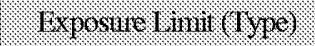 & 10.11. l.evel. & 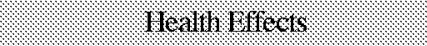 \\
\hline Acetylene Tetrabromide, CAS No. $79-7-6$ & 1 ppm (PEL/TWA) & $10 \mathrm{ppm}$ & $\begin{array}{l}\text { Nose and eye irritant. Ingestion may } \\
\text { cause nausea, headache, and } \\
\text { abdominal pain. Contact may cause } \\
\text { pain, jaundice, monocytosis. }\end{array}$ \\
\hline Asbestos, CAS No. $1332-21-4$ & $\begin{array}{l}0.1 \mathrm{f} / \mathrm{cc}(\mathrm{PEL} / \mathrm{TWA}) \\
1.0 \mathrm{f} / \mathrm{cc}(\mathrm{STEL})\end{array}$ & Carcinogen & $\begin{array}{l}\text { Causes chronic lung disease } \\
\text { (asbestosis), inflammation of the } \\
\text { pleura, and certain cancers of the } \\
\text { lungs and digestive tracts. }\end{array}$ \\
\hline Hexone, CAS No. $108-10-1$ & $\begin{array}{l}50 \text { ppm (PEL/TWA) } \\
75 \text { ppm (STEL) }\end{array}$ & $3000 \mathrm{ppm}$ & $\begin{array}{l}\text { Mucous membrane and eye irritant. } \\
\text { Ingestion may cause headache, } \\
\text { narcosis, coma and dermatitis. }\end{array}$ \\
\hline Lead, CAS No. 7439-92-1 & $0.05 \mathrm{mg} / \mathrm{M}^{3}$ (PEL/TWA $)$ & $700 \mathrm{mg} / \mathrm{M}^{3}$ & $\begin{array}{l}\text { Prolonged absorption of lead may } \\
\text { result in weakness, tremors, } \\
\text { abdominal pain encephalopathy and } \\
\text { anemia. }\end{array}$ \\
\hline Mercury, CAS No. 7439-97-6 & $0.05 \mathrm{mg} / \mathrm{M}^{3}$ (PEL/TWA) & $28 \mathrm{mg} / \mathrm{M}^{3}$ & $\begin{array}{l}\text { Absorption may produce tremors, } \\
\text { bronchitis and pneumonitis, chest } \\
\text { pain, coughing, and may have other } \\
\text { respiratory and central nervous } \\
\text { system effects. }\end{array}$ \\
\hline Methylene Chloride, CA No. 75092 & $\begin{array}{l}500 \text { ppm (PEL/TWA) } \\
1000 \text { ppm ceiling }\end{array}$ & $\begin{array}{l}5000 \text { ppm } \\
\text { Carcinogen }\end{array}$ & $\begin{array}{l}\text { May cause fatigue, weakness, } \\
\text { dizziness, numbness in the limbs, } \\
\text { nausea, and imitated eyes. }\end{array}$ \\
\hline
\end{tabular}




\begin{tabular}{|c|c|c|c|}
\hline Silostaince & Expostire linit T Y y. & 19.1.1. & 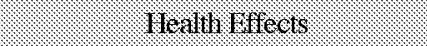 \\
\hline \multicolumn{4}{|l|}{ Neptunium, } \\
\hline Nitric acid, CAS No. 7697-37/2 & $\begin{array}{l}2 \mathrm{ppm}(\mathrm{PEL} / \mathrm{TWA}) \\
4 \mathrm{ppm}(\mathrm{STEL})\end{array}$ & 100 ppm & $\begin{array}{l}\text { Causes corrosion of the skin and } \\
\text { other tissue from direct contact. } \\
\text { Acute pulmonary edema or chronic } \\
\text { obstructive pulmonary disease from } \\
\text { inhalation. }\end{array}$ \\
\hline $\begin{array}{l}\text { Polychlorinated biphenyls (PCBs), CAS Nos. } \\
11097-69-1,5346921-9\end{array}$ & $\begin{array}{l}0.5 \mathrm{mg} / \mathrm{M}^{3} \text { skin } \\
\text { (PEL/TWA) }\end{array}$ & $\begin{array}{l}5 \mathrm{mg} / \mathrm{M}^{3} \\
\text { Carcinogen }\end{array}$ & $\begin{array}{l}\text { Irritant of the eyes and mucous } \\
\text { membranes; is toxic to the liver, and } \\
\text { causes chloracne. It is a liver } \\
\text { carcinogen in animals. }\end{array}$ \\
\hline Plutonium & See applicable RWP. & Not available & $\begin{array}{l}\text { Toxic and carcinogenic; targets } \\
\text { gastro-intestinal tract; kidneys, lungs. }\end{array}$ \\
\hline \multicolumn{4}{|l|}{ Ruthenium } \\
\hline Silica, crystalline, CA No. $14808-60-7$ & $0.05 \mathrm{mg} / \mathrm{M}^{3}$ (PEL/TWA) & Carcinogen & $\begin{array}{l}\text { May cause impaired pulmonary } \\
\text { function (coughing and wheezing). }\end{array}$ \\
\hline Uranium & $0.05 \mathrm{mg} / \mathrm{M}^{3}$ (PEL/TWA) & $\begin{array}{l}20 \mathrm{mg} / \mathrm{M}^{3} \\
\text { Carcinogen }\end{array}$ & $\begin{array}{l}\text { Toxic and carcinogenic. May cause } \\
\text { respiratory damage, vomiting, and } \\
\text { skin burns. }\end{array}$ \\
\hline
\end{tabular}

Note: A MSDS for each of the above substances will be on site (i.e., in the support zone).

On-site injury or illness. In the event of any injury requiring more than minor first aid, or any employee reporting any sign or symptom of exposure to hazardous substances, immediately take the victim to 200W Area First Aid station (open M-F, 7:30 -4:00) located at Building 2719WA/200W, see Figure 3. Phone $\underline{373-2714}$.

In the event of life-threatening or traumatic injury, implement appropriate first aid and immediately call for emergency medical assistance at 911 by plant telephone, or $373-3800$ by cellular telephone. The nearest designated trauma center is Kadlec Medical Center, Richland. Phone 946-4611. Locations of the Medical/First-Aid stations on the Hanford Site are shown on Figure $\underline{3}$. 


\section{PERSONAL MONITORING}

All working personnel wearing respiratory protection (for radiological purposes) shall be on a $\mathrm{Pu}$ bioassay program.

The preliminary hazards assessment does not indicate a requirement to conduct personal monitoring. However, personal monitoring may be conducted should the SSO determine, with concurrence from the Health \& Safety Officer, that reevaluation is necessary due to changes in site conditions. This additional monitoring may be conducted in accordance with a sampling strategy developed for the specific task.

\section{AMBIENT AIR AND SITE MONITORING PROCEDURES}

Radiological air sampling shall be conducted to trend and record air contaminant concentrations. The use of lapel air samples may be required during certain work evolutions to monitor the worker's breathing zone. Continuous Air Monitors (CAMs) shall be placed strategically inside the facility. The CAMs will alert personnel to increased levels of airborne radioactivity or when the potential to exceed respiratory protection factors exist. When it is suspected there has been an inhalation, ingestion, or injection of radioactive material the RCT Supervisor with assistance of the Radiological Engineer shall notify BHI's Internal Dosimetry department and ask for assistance in providing the appropriate bioassay.

The following instruments are anticipated to be used routinely to monitor the work environment and worker's breathing zones prior to site entry and at the specified intervals.

\begin{tabular}{|c|c|c|c|c|c|c|c|}
\hline \multirow[b]{2}{*}{$\mathrm{X}$} & \multirow{2}{*}{$\begin{array}{l}\text { Instrument } \\
\text { PID (OVM) w/ } 10.6 \mathrm{eV} \text { lamp } \\
\& / \mathrm{or} 11.8 \mathrm{eV} \text { lamp }\end{array}$} & \multicolumn{5}{|c|}{$\begin{array}{l}\text { Monitoring Frequency } \\
\text { (Circle choice or fill in info. in other category) }\end{array}$} & \\
\hline & & Cont. & $15 \mathrm{~min}$. & $30 \mathrm{~min}$. & Hourly & Other: & $\underline{\text { see below }}$ \\
\hline & OVA & Cont. & $15 \mathrm{~min}$. & 30min. & Hourly & Other: & \\
\hline$\underline{X}$ & Combustible Gas Indicator $/ \mathrm{O}_{2}$ Meter & Cont. & $15 \mathrm{~min}$. & $30 \mathrm{~min}$. & Hourly & Other: & see below \\
\hline & $\mathrm{H}_{2} \mathrm{~S}$ Detector & Cont. & $15 \mathrm{~min}$. & $30 \mathrm{~min}$. & Hourly & Other: & \\
\hline$X$ & $\begin{array}{l}\text { Colorimetric Detector Tubes } \\
\text { (list types of tubes/manuf. below) }\end{array}$ & Cont. & $15 \mathrm{~min}$. & $30 \mathrm{~min}$. & Hourly & Other: & see below \\
\hline & pH Paper & Cont. & $15 \mathrm{~min}$. & $30 \mathrm{~min}$. & Hourly & Other: & \\
\hline
\end{tabular}


Other Types of Monitoring/Additional Information:

C PID -The PID will be used to monitor the work area whenever a potential exposure exists. If potential exposure exists, monitoring should be performed prior to work start, at the time of any change in work conditions or work activities (i.e., new activities). Both the $10.6 \mathrm{eV}$ and $11.7 \mathrm{eV}$ lamps will be used as determined appropriate by the SSO. If radiological PPE requirements exceed those required for chemical contamination, the monitoring frequency may be changed and/or done remotely as determined by the SSO.

C Combustible Gas Indicator (CGI)/02 Meter -CGI monitoring will be conducted prior to any activity which may produce a spark or flame. The presence of hydrogen gas will be detected with the CGI.

C Colorimetric detector tubes will be utilized when suspect odors are encountered, or if PID readings are above background. If interference between chemicals is encountered (mixtures), the chemical with the lowest PEL/TLV will be used to determine the appropriate PPE. Additional $\mathrm{IH}$ monitoring may be required.

C Temperature - If the dry bulb temperature reaches $20 \mathrm{EC}$ or $90 \mathrm{EF}$, monitoring will be conducted, and personnel will follow guidance stated in BHI-SH-02, Vol. 3, Procedure 4.1.2, "Temperature Extremes."

C Anemometer -Wind speed will be determined using a portable anemometer (or by calling the PNNL weather station at 373-2716). A portable anemometer will be available at the work site. A wind sock will also be present at the site in the support zone to indicate wind direction.

C Noise -Noise levels will be monitored periodically during operation of heavy machinery.

\section{BIOLOGICAL MONITORING/MEDICAL SURVEILLANCE}

YES This project requires medical surveillance or biological monitoring procedures beyond the provisions of the routine medical surveillance program (see description below).

Description: Blood Lead Program (if working with lead)

Asbestos Worker Physical (if working with asbestos) 


\section{ACTION LEVELS}

Field team personnel shall observe the following Action Levels:

\begin{tabular}{|c|c|c|}
\hline Instrument & Action Level & Specific Action \\
\hline PID, both lamps & $\begin{array}{l}\text { 1. One ppm in breathing zone for three minutes or } \\
\text { more. } \\
\text { 2. } 10 \text { ppm peak (not necessarily sustained) in } \\
\text { breathing zone. }\end{array}$ & $\begin{array}{l}\text { 1. Stop work, fall back upwind of area. Level B } \\
\text { PPE will be used. } \\
\text { 2. Possible upgrade to level of PPE; SSO makes } \\
\text { the determination. } \\
\text { 3. Additional IH monitoring may be required if } \\
\text { the PID or Draegel tubes show indication. }\end{array}$ \\
\hline $\mathrm{CGI} / \mathrm{O}_{2}$ & $\begin{array}{l}\text { Monitor during activities when combustible gases } \\
\text { including hydrogen could be present: monitoring } \\
\text { during any activity that could produce sparks or } \\
\text { ignition sources and when flammable gases may } \\
\text { be present. }\end{array}$ & $\begin{array}{l}\text { 1. Attempt to identify substance. Continue } \\
\text { work. } \\
\text { 2. Use non-sparking equipment or tools in area } \\
\text { being monitored. (See Item } 8 \text {, } \\
\text { Fire/Explosion Hazards; all actual } \\
\text { uncovering/exposing of drums will be done } \\
\text { with non-sparking hand tools.) }\end{array}$ \\
\hline $\begin{array}{l}\text { Colorimetric (Draeger } \\
\text { tubes) }\end{array}$ & $\begin{array}{l}\text { 1. Will only be used for qualitative testing. } \\
\text { 2. Will be used for initial monitoring for nitric } \\
\text { acid. }\end{array}$ & $\begin{array}{l}\text { 1. Respiratory protection may be changed } \\
\text { depending on compounds and levels detected. } \\
\text { If levels are } 50 \% \text { of any published exposure } \\
\text { levels, additional Item } 9 \text { precautions, such as } \\
\text { upgrading other PPE and changing work } \\
\text { practices, will be taken. } \\
\text { 2. If any detectable levels ( } 2 \text { ppm or greater) of } \\
\text { nitric acid are noted, Level B PPE (air- } \\
\text { supplied respirator and chemically protective } \\
\text { clothing) will be used. } \\
\text { 3. Additional IH monitoring may be required if } \\
\text { the PID or Draegel tubes show indication. }\end{array}$ \\
\hline
\end{tabular}

NOTE: If substances are identified that are different than those listed in Item 9, PPE levels will be adjusted according to toxicity. 


\section{ON-SITE CONTROL}

Control boundaries have been established, and the Exclusion Zone, Contamination Control Zone, and Support Zone have been designated and are identified as follows:

Support Zone -Area outside of the controlled contamination zones (i.e., contamination reduction and exclusion zones; these areas will be fenced in or roped off). This area is a clean zone.

Contamination Reduction Zone -Area between the exclusion zone and the support zone, used for controlling the spread of contamination. Decontamination lines (as appropriate) will be located in this area, upwind of the actual work taking place. Some team members may be stationed in and conduct work in this zone.

Exclusion Zone -Inner work area, known or highly probable contamination, designated by marker tape around the immediate work area.

\section{PERSONAL PROTECTIVE EQUIPMENT}

\begin{tabular}{|c|c|c|c|c|c|}
\hline Location & Job Function/Task & \multicolumn{2}{|c|}{ Level of Protection } & & \\
\hline Contamination Reduction Zone & Support tasks & A & B & $\mathrm{C}$ & $(\mathrm{D})^{*}$ \\
\hline Exclusion Zone & All tasks & $\mathrm{A}$ & B & $(\mathrm{C})^{*}$ & $\mathrm{D}$ \\
\hline Support Zone & No protection & A & B & $\mathrm{C}$ & $\mathrm{D}$ \\
\hline
\end{tabular}

Rationale: Level "D" is required initially for site setup activities. The SSO will (at least twice daily) monitor each site, where a potential exposure exists, and if one is found [i.e., detectable level ( $2 \mathrm{ppm}$ or greater) of nitric acid using a colorimetric tube, or one ppm or greater concentration of organic vapor using a PID], the level of protection will be upgraded to Level "C" or "B" or "A" as determined by the SSO.

If additional substances that are hazardous to worker health and present in concentrations of concern (other than those identified in Item 9), Level "B" or "A" PPE will be used until it can be determined what level of PPE is appropriate for the hazard.

As noted in Item 13, personnel in the contamination zone will work upwind (if possible). If it appears from air monitoring that personnel exposures outside the exclusion zone are likely, then respiratory protection for these personnel will be worn or they will move further upwind from the source of the exposure. Boundaries of the contamination reduction and exclusion zone will also be adjusted outward to contain the area of potential exposure. 
List the specific protective equipment and material (where applicable) for each of the Levels of Protection identified previously:

LEVEL A: To be selected when the greatest level of skin, respiratory, and eye protection is required.

1. Positive pressure, full face-piece self contained breathing apparatus (SCBA), or positive pressure supplied air respirator with escape SCBA, approved by the National Institute for Occupational Safety and Health (NIOSH).

2. Totally-encapsulating chemical-protective suit. 3. Coveralls ${ }^{1}$. 4. Long underwear ${ }^{1}$. 5. Gloves, outer, chemical-resistant. 6. Gloves, inner, chemical-resistant. 7. Boots, chemical-resistant, steel toe and shank. 8. Hard hat (under suit) ${ }^{1}$. 9. Disposable protective suit, gloves and boots (depending on suit construction, may be worn over totally-encapsulating suit).

LEVEL B: The highest level of respiratory protection is necessary but a lesser level of skin protection is needed.

1. Positive pressure, full-facepiece self-contained breathing apparatus (SCBA), or positive pressure supplied air respirator with escape SCBA (NIOSH approved). 2. Hooded chemical-resistant clothing (overalls and long-sleeved jacket; coveralls; one or two piece chemical-splash suit; disposable chemical-resistant overalls. 3. coveralls ${ }^{1}$. 4. Gloves, outer. chemical-resistant. 5. Gloves, inner, chemical-resistant. 6. Boots, outer, chemical-resistant steel toe and shank. 7. Boots-eovers, outer, chemicalresistant (disposable) ${ }^{1}$. 8. Hard hat. ${ }^{1}$. 9. Face shield ${ }^{1}$.

LEVEL C: The concentrations (s) and type (s) of airborne substances (s) is known and the criteria for using air purifying respirators are met.

1. Full-face or half-mask, air purifying respirators (NIOSH approved). 2. Hooded chemical-resistant clothing (overalls; twopiece chemical-splash suit; disposable chemical-resistant overalls). 3. Coveralls ${ }^{\perp}$. 4. Gloves, outer, chemical-resistant. 5. Gloves, inner, chemical-resistant. 6. Boots (outer), chemical-resistant steel toe and shank ${ }^{1}$. 7. Boot-overs, outer, chemicalresistant (disposable) ${ }^{1}$. 8. Hard hat ${ }^{1}$. 9. Escape mask ${ }^{1}$. 10. Face shield ${ }^{1}$.

LEVEL D: A work uniform affording minimal protection, used for nuisance contamination only.

1. Coveralls. 2. Gloves'. 3. Boots/shoes, chemical-resistance steel toe and shank. 4. Boots. outer, chemical-resistant (disposable) $^{1}$. 5. Safety glasses or chemical splash goggles. 6. Hard hat ${ }^{1}$. 7. Escape mask ${ }^{1}$. 8. Face shield ${ }^{1}$.

${ }^{1}$ Optional.

\section{NO CHANGES TO THE SPECIFIED LEVELS OF PROTECTION SHALL BE MADE WITHOUT THE KNOWLEDGE AND APPROVAL OF THE HEALTH AND SAFETY OFFICER AND RADIOLOGICAL CONTROL.}

\section{DECONTAMINATION}

Emergency Decontamination procedures: Serious personal injury takes precedence over decontamination procedures. Do not attempt personal decontamination if the injury will be aggravated. An injured person should first be removed from immediate danger (if possible to move without further injury). Then, if it is determined necessary by the SSO and RCT, decontamination can take place prior to leaving the site for medical treatment. Emergency decontamination facilities are located at 222-S, $100-\mathrm{N}$, and KADLEC Medical Center. If the extent of personal injury is unknown, Emergency Medical Response personnel (Hanford Fire Department) will make the decision to move the injured person. The RCT and SSO may have to escort the injured person to the hospital. 


\section{Decontamination Equipment}

The following decontamination equipment is required:

C potable water

C various types and sizes of scrub brushes

C spill absorbent

C grate(s)

C non-phosphate (biodegradable) detergent

$\mathrm{C}$ wipes/towels

C buckets/wash tubs

17. RADIOLOGICAL CONDITIONS (Refer to applicable RWP.)

\section{RADIOLOGICAL CONTROL TECHNICIAN COVERAGE}

None _ Intermittent $\underline{X}$ Continuous - Refer to appl. RWP.

RCT Coverage Required When: Personnel are working in a CA/HCA/ARA/RA/HRA.

Authorized Radiological Control Technicians: RCT Pool -Contact: K. A. Mathews 373-9107

\section{PERSONAL PROTECTIVE EQUIPMENT FOR RADIOLOGICAL HAZARDS}

X Refer to appl. RWP.

PPE for radiological work is addressed in BHI-SH-04 and the HSRCM. During certain phases of work where the potential to exceed a respiratory protection factor for fresh air with ska-pak, a bubble hood with APR inside may be worn. When this configuration is worn, a lapel air sampler shall be located to sample the air between the bubble hood and the APR. The lapel air sampler will be the record sample and the APR protection factor will be used for calculating airborne radioactivity concentrations personnel have been exposed to. 
20. RADIATION DOSIMETRY EXTERNAL (Refer to appl. RWP.)

\section{RADIATION MONITORING (Refer to appl. RWP.)}

Radiological monitoring shall be performed in accordance with BHI-SH-04, HSRCM, and applicable technical assessments 
22. ON-SITE ORGANIZATION AND COORDINATION (To be completed on site)

Project Coordinator: S. D.Thoren (or designee)

Project Superintendent: C.W. Blankingship (or designee)

Site Safety Officer: SSO Pool provided by ERC Safety and Health

Designated Radiological Control Technicians: _RCT Pool, TBD

Alternate Radiological Control Technicians: RCT Pool, TBD

\section{TRAINING/SPECIAL REQUIREMENTS}

All field team members will have received the initial 40 -hour hazardous waste worker training (per 29 CFR 1910.120(e)). The SSO and all site supervisors will have received the additional 8 hours of supervisor/manager training (per 29 CFR 1910.120(e)). All employees will be current with their 8hour refresher training (per 29 CFR 1910.120(e)) and medical surveillance (per 29 CFR 1910.120(f)). Documentation of training and medical approval for wearing PPE and performing hazardous waste work must be present on-site. This documentation will be kept by the Supervisor in the support zone. Any team member having a work restriction must report this to their manager, and they in turn must report it to the Supervisor prior to beginning site work. All visitors must report to the Supervisor when they show up on site. Visitors (non-team members) access will be limited to the support zone, unless they meet full training requirements (same as field team members) and have a need to go into the contamination reduction and exclusion zones (this access will be controlled by the Supervisor and will conform with ALARA principles at all times). Additional requirements for visitors who want to enter the above zones will be as follows:

C Visitors must give 24 hours prior notice of visit.

C Visitors must provide proof of training and medical surveillance in order to be allowed entry.

C They must fill out the visitor log and sign in and out with the Supervisor.

C They must follow the same rules and wear the same PPE as any team member in the above zones.

C All visitors (non-team members) will be escorted by a fully trained individual (having completed 40 -hour training and 24 hours of field experience) when in the above zones. 


\section{SANITATION REQUIREMENTS}

Potable water supply available on work site?

Portable toilets required at work site?

Portable toilets available at work site?

Temporary washing/shower facilities required at work site?
$\underline{X}$ Yes

$\underline{\mathrm{X}}$ Yes If yes, how many? 1 No

$\underline{\mathrm{X}}$ Yes If yes, how many? 1 Yes If yes, describe below. $\underline{\mathrm{X}}$ No If no, state location of nearest facility that can be used. $(271 \mathrm{U})$

\section{EMERGENCY PROCEDURES}

\section{Emergency Plan}

C Purpose:

This section outlines the methods and responsibilities employed at the $233-S$ project to lessen the potential impact on the workers, public, and the environments, should an emergency occur at this project. Appropriate personnel, equipment, and trained personnel have been identified to ensure that any conditions that do arise can be properly handled. All emergency response will be per the applicable emergency implementing procedures in BHI-SH-03, Emergency Management Program and will comply with DOE Orders, State, and Federal Regulations. 


\section{Emergency Alerting/Notification:}

The project will be notified of an Area emergency by telephone or Area Emergency Sirens. All emergency notifications/communications will then be communicated to personnel by telephone, radio, or the use of runners.

1. Hanford Site Emergency Signals (see figure XX)

2. Three manual fire alarms are located at the exits, detectors are located in the process hood, loadout room, support rooms and the SA building. All respond to the fire alarm panel located in the changeroom.

3. Radios and cellular telephones

4. Word of mouth or runners

5. 233-S Fire Alarm Bells 
C Emergency communication Telephone Numbers:

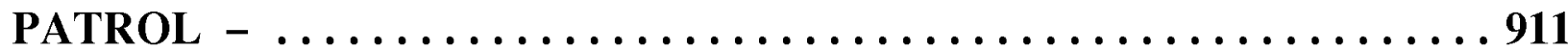

Cellular Telephones ........................... 373-3800

Non Emergency/Business ....................... 373-3800

HANFORD FIRE DEPARTMENT $\ldots \ldots \ldots \ldots \ldots \ldots \ldots \ldots \ldots, \ldots \ldots \ldots 37-2745$

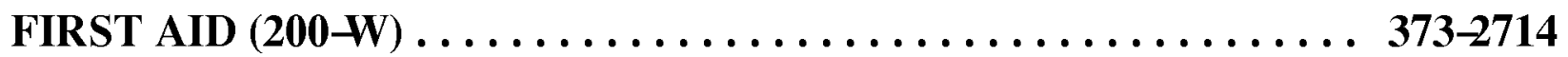

BHI Occurrence Notification Reporting Administrator . . . . . . . . 372-9257

NORTHERN AREA EMERGENCY CONTROL CENTER (N. A. ECCB73-1786 second telephone number $\ldots \ldots \ldots \ldots \ldots \ldots \ldots \ldots \ldots \ldots \ldots . \ldots \ldots 373-3876$

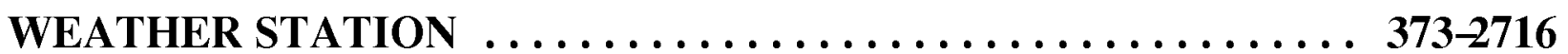

SPILL REPORTING ................... 85-7815 or 373-4315 or see Hanford Info "Spill/Release Contact Personnel ... (HLAN Computer)

BHI Emergency Management Administrator $\ldots \ldots \ldots \ldots \ldots \ldots \ldots . \ldots 372-9252$

Pager ................................. 85-7354

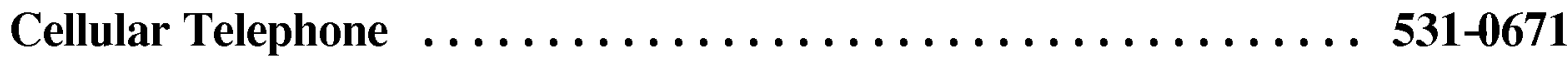

BHI Single Point Of Contact (SPOC) . . . . . . . . 85-5712, 531-0619 


\section{Emergency Evacuation Procedure:}

When workers observe a hazardous condition that they have not been prepared for, they will withdraw from the area (evacuate) and call the Building Emergency Director (BED), who will make notifications as required. The building will be evacuated, the situation evaluated, and decisions will be made regarding mitigation and further response.

1. If personnel are notified to evacuate the building (i.e., Area Emergency Sirens, by radio, or cellular telephone), exit through the normal means of egress, or if in imminent danger through the nearest exit. Personnel should follow all radiological egress procedures unless in imminent danger.

2. Help disabled, injured or impaired persons to evacuate the affected area.

3. Report to the designated staging area. If wearing PPEs, stay clear and down wind from personnel in the staging area.

4. Inform the person(s) performing personnel accountability of any personnel remaining at the affected evacuation area.

Note: Personnel should always stage upwind.

\section{Evacuation Route(s)/Staging Area (primary and alternate):}

The designated staging areas are shown in Figure $\mathrm{X}$ in conjunction with the evacuation routes. All affected personnel should assemble at the staging area and maintain a safe distance from response personnel and equipment unless requested to provide assistance by the BED.

\section{Personnel Accountability:}

1. Obtain a listing of all personnel working in the building and all visitors to the project.

2. Ensure that all personnel at the project (logged in) are accounted for when reaching the staging area.

3. Inform the Building Emergency Director (BED) of the status of accountability.

4. The BED or designee will communicate accountability status to the Hanford Site Emergency Response Organization at the following numbers: $373-1786$ or $373-3876$. 
C Emergency Response Organization:

\begin{tabular}{|c|c|c|c||}
\hline \hline Designation & Title & Work Location & Work Phone \\
\hline \hline Primary BED & & & \\
\hline Alternate BED & & & \\
\hline
\end{tabular}

The BED or his/her designated alternate has the overall responsibility for implementing emergency procedures and this plan. The Hanford Site Emergency Preparedness Organization maintains a listing of BED names, work and home telephone numbers and this information be may be obtained 24 hours a day via the Patrol Operations Center.

The BEDs have the authority to commit all necessary resources (both equipment and personnel) to respond to any emergency. All emergency mitigation will be per the BHI emergency implementing procedures or DOE/RL emergency implementing procedures. Additional responsibilities have been delegated to the Hanford Fire Department.

Descriptions of additional response support and the arrangements for out side responders may be viewed in DOE/RL-94-02, Hanford Emergency Response Plan. 
Emergency Equipment

\begin{tabular}{|c|c|c|}
\hline \multicolumn{3}{|c|}{ Fixed Emergency Equipment } \\
\hline Type & Location & Capability \\
\hline Fire Alarms & 233-S Building & Summons Emergency Response \\
\hline \multicolumn{3}{|c|}{ Portable Emergency Equipment } \\
\hline Fire Extinguisher & 233-S Building & Small Fire Suppression \\
\hline Eye Wash or Showers & 233-S Building & \\
\hline \multicolumn{3}{|c|}{ Communication Equipment/Warning Systems } \\
\hline \multicolumn{3}{|c|}{$\begin{array}{l}\text { Hanford Site-wide audible alarms will be observed. Best management practice requires that Facility } \\
\text { personnel have access to a two-way radio. Land line telephone is located in } 233-S \text { Command } \\
\text { Trailer. }\end{array}$} \\
\hline Two-Way Radio & 233-S Command Trailer & Summons Emergency Response \\
\hline \multicolumn{3}{|c|}{ Spill Kits and Spill Control Equipment } \\
\hline Standard Spill Kit & 233-s Building & Small Spill Cleanup \\
\hline \multicolumn{3}{|c|}{ Personal Protective Equipment } \\
\hline $\begin{array}{l}\text { Safety glasses, appropriate } f \\
\text { perimeter fence. }\end{array}$ & and hardhats are requirec & all personnel entering the Redox \\
\hline
\end{tabular}

C Decontamination Procedures:

Radiological decontamination procedures are located in Section 5.0 of BHI-SH-04, Radiological Control Work Instructions. 
Training is one of the first steps of being prepared for an emergency. All members of the Building Emergency Organization (i.e., BED) and employees shall complete the proper training as discussed below and as required by BHI-SH- -3 , Emergency Management Program. Initial and annual review of the 233-S project Safety and Health Plan is required and shall be documented. Review of the HASP initially and annually will suffice for the requirement that personnel review the Building Emergency Plan.

* Members of the ERO shall be trained per BHI-SH-03 prior to being assigned ERO responsibilities, and annually thereafter. Persons will be listed in the "emergency plan" section of the HASP. The ERO will be made up of, at a minimum, a primary and alternate BED. Other positions will be trained as requested.

* 233-S workers shall review the HASP initially when hired or assigned to the project, when the employees responsibilities or designated actions under the plan change, when the plan is revised, and at least annually thereafter.

* Visitors shall be briefed on the emergency plan when visiting the project site, in addition to reviewing the Hanford Site Emergency Signals. 
Figure $X$ :

\section{Evacuation Route and Staging Area(s)}

(Evacuation routes to be continually updated by the Health \& Safety Officer in accordance with changing facility conditions) 


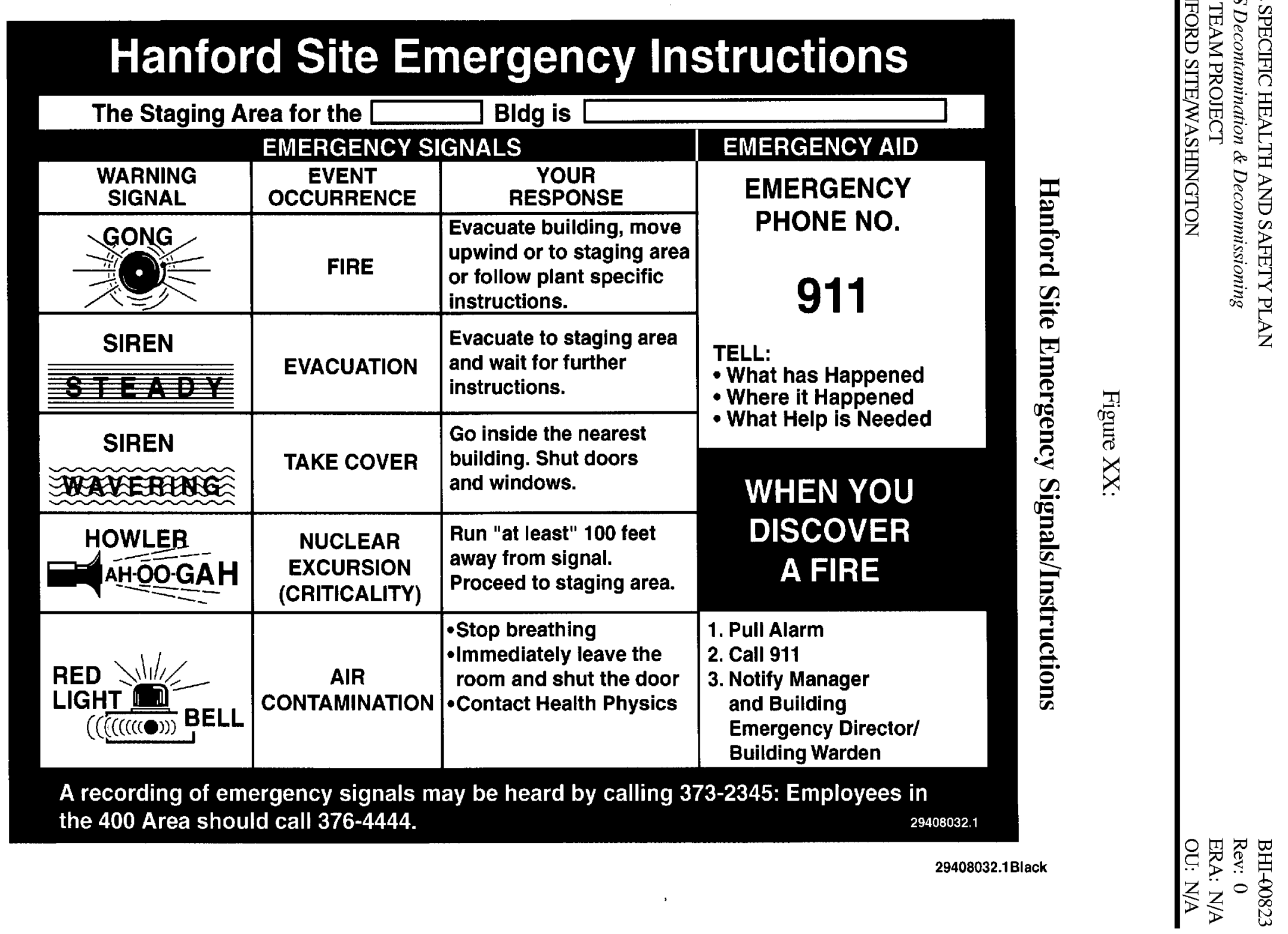


$\mathrm{X}$ Yes _ No On-site communications required? Emergency channel 911 (plant telephone), 373-3800 (cellular)

Nearest telephone (location, number) 233-S Site Trailer

Nearest first aid station: 2719WA/200W, Monday -Friday, 7:30 -4:00, 373-2714

2719EA/200E, Monday -Friday, 7:30 -4:00, 373-2314

Fire and Explosion. Evacuate the area, ensure the Hanford Fire Department and the Building Emergency Director have been notified. Follow the emergency evacuation procedure of this plan as trained. 
Additional Emergency Procedure information can be found in the Work Plan.

\section{Designated Personnel Current in First-Aid/CPR (Names)}

Name

C. W. Blankingship (Superintendent)

$$
\text { J. E. Fasso (SSO) }
$$

\section{J. L. Davis (Craft Supervisor)}

Designated Back-Up Personnel
Function

Adm. first aid/CPR

Adm. first aid/CPR

Adm. first aid/CPR

At least two personnel per shift shall be first aid trained.

\section{Emergency Response Authority}

The Building Emergency Director (BED)/Emergency Coordinator (EC) has initial authority for firstresponse to on-site emergency situations.

Upon arrival of the appropriate emergency response personnel, the BED/EC shall defer all authority to the Incident Commander (of the response team), but shall remain on the scene to provide assistance, if necessary, and to ensure all responsibilities pertained in the emergency implementing procedures (BHISH-03) have been completed. At the earliest opportunity, the Site Safety Officer of the BED/EC shall contact the ERC Project Coordinator and/or Health and Safety Officer.

Upon arrival of the appropriate emergency response personnel, the Site Emergency Coordinator shall defer all authority to the Incident Commander (of the response team), but shall remain on the scene to provide assistance if necessary. At the earliest opportunity, the Site Safety Officer or the Site Emergency Coordinator shall contact the ERC Project Coordinator and/or Health and Safety Officer.
Project Coordinator
S.D. Thoren
Phone (w) $\underline{373-4033}$
(h) $\underline{N} / \mathrm{A}$
Health and Safety Officer M. N. Kenter Phone (w)
(h) $\underline{N} / \mathrm{A}$

NOTES: A copy of the emergency procedures section of this HASP will be posted at the work site. In addition, entire HASP will be available in the support zone at the work site (Supervisor will have the responsibility for keeping it available.) 


\section{APPENDIX A}

\section{FIELD CHANGE AUTHORIZATION}

$\begin{array}{ll}\begin{array}{l}\text { Instruction Number } \\ \text { to be changed }\end{array} & \text { Duration of Authorization Requested } \\ & \quad \text { Today Only } \\ & \quad \text { Duration of Task }\end{array}$

Description of Field Change Modification:

Justification:

Person Requesting Change:

Title

Signature

Concurrence:

RCT Supervisor
Verbal Authorization Received From:

Name

Time
Approved By (Signature of person named above to be obtained within 48 hours of verbal authorization) 
Figure 1. Map of Work Locations 
Figure 2A. Site Work Zone Set-Up -Site 1. Page 1 of 3 
Figure 2B. Site Work Zone Set-Up -Sites 2-4. Page 2 of 3 
Figure 2C. Site Work Zone Set-Up -Site 5. Page 3 of 3 


\section{DISTRIBUTION}

ONSITE (19)

$\begin{array}{ll}\text { C. W. Blankingship } & \text { X0-17 } \\ \text { G. J. Carter } & \text { X5-15 } \\ \text { R. G. Egge } & \mathrm{T} 7-05 \\ \text { J. E. Fasso } & \mathrm{T} 7-15 \\ \text { J. R. Hensley } & \mathrm{T} 7-15 \\ \text { P. K. Jackson } & \mathrm{X} 5-53 \\ \text { M. N. Kenter } & \mathrm{X} 0-34 \\ \text { R. D. Lichfield } & \mathrm{H} 0-15 \\ \text { J. J. Mcguire } & \mathrm{X} 5-53 \\ \text { J. P. Pizzarella } & \mathrm{X} 0-17 \\ \text { K. A. Smith } & \mathrm{X} 0-34 \\ \text { S. D. Thoren } & \mathrm{X} 5-53 \\ \text { J. Vaughn } & \mathrm{H} 0-15\end{array}$

Document and Information Services (4) $\quad \mathrm{H} 0-09$

Safety ltrbk/lib H0-15

PNNL Technical Library P8-55 